E ISSN : $2302-1810$

DOI : doi.org/1021009/wahana-akuntansi/12.1.05

\title{
PENGARUH PERBEDAAN TEMPORER ANTARA LABA AKUNTANSI DAN PAJAK, PROPRIETARY COST, DAN LIKUIDITAS TERHADAP PERTUMBUHAN LABA
}

\author{
AYUMASTUTININGSIH \\ NURAMALIA HASANAH \\ RIDA PRIHATNI \\ Email: Amalia1715@yahoo.co.id \\ Fakultas Ekonomi Universitas Negeri Jakarta
}

\begin{abstract}
This study aimed to examine the influence of temporary differences between accounting profit and tax, proprietary costs, and Liquidity toward earnings growth of the companies listed in Indonesia Stock Exchange (IDX) 2011-2012. The factors examined in this study are temporary differences between accounting profit and tax, proprietary costs, and liquidity as an independent variable, while earnings growth has the dependent variable. This study used a descriptive quantitative method using secondary data and the number of samples collected was thirty-eight (38) that have met the criteria the researchers used purposive sampling. From the data that has been collected and then processed and analyzed using multiple regression analysis with a significance level of 0.05 .

This research proves temporary differences between accounting profit and tax has no significant influence on earnings growth, proprietary cost has no significant influence on earnings growth, and liquidity has negatively significant influence earnings growth. Temporary differences between accounting profit and tax, proprietary costs, and liquidity together or simultaneously significant influence toward the earnings growth.
\end{abstract}

Keywords : temporary differences between accounting profit and tax, proprietary costs, liquidity, earnings growth.

\section{PENDAHULUAN}

Setiap perusahaan publik pasti memiliki laporan keuangan. Laporan keuangan itu sendiri berguna bagi pihak internal dan eksternal perusahaan. Dalam rangka mengeluarkan laporan keuangannya ke pihak internal dan eksternal, sesungguhnya perusahaan ingin menunjukkan bahwa keadaan keuangan perusahaan dalam keadaan yang baik dimana pertumbuhan laba yang meningkat di tiap tahunnya agar para investor tertarik untuk berinvestasi. Kebanyakan manajemen dari suatu perusahaan berpikir bahwa pertumbuhan

Jurnal Ilmiah Wahana Akuntansi

Volume 12 No.01, Tahun 2017 
E ISSN : $2302-1810$

DOI : doi.org/1021009/wahana-akuntansi/12.1.05

perusahaan harus tinggi dikarenakan semakin tinggi tingkat pertumbuhan perusahaan maka pendapatan dan laba perusahaan akan bertambah. Apabila pendapatan dan laba perusahaan akan bertambah tiap tahunnya maka pertumbuhan laba juga akan meningkat sehingga investor tertarik berinvestasi. Investor melihat apabila pertumbuhan laba perusahaan meningkat maka investor akan tertarik berinvestasi dan mendapatkan pengembalian dividen yang besar. Namun, apabila dilihat dari aspek finansial perusahaan, pertumbuhan laba tidak selalu merupakan hal yang positif. Tingkat pertumbuhan laba yang meningkat terlalu tinggi dan cepat akan menyebabkan kebutuhan modal kerja (working capital) menjadi semakin tinggi. Hal ini memunculkan fenomena dan fakta yang menyedihkan apabila manajer tidak mampu mengevaluasi pertumbuhan laba nya dengan baik, akan berdampak kesulitan keuangan perusahaan yang disebabkan oleh terlalu tingginya tingkat pertumbuhan sama besar kemungkinannya dengan kesulitan keuangan akibat pertumbuhan yang rendah. Namun faktanya, laba yang diperoleh perusahaan dari tahun ke tahun tidak dapat dipastikan, bisa naik untuk tahun ini dan bisa turun untuk tahun berikutnya. Kenaikan dan penurunan laba pertahun inilah yang disebut dengan pertumbuhan laba. Pertumbuhan laba dapat dilihat dalam laporan keuangan komersial. Laporan keuangan komersial disusun berdasarkan standar akuntansi keuangan yang berlaku. Selain menyusun laporan keuangan komersial, perusahaan juga menyusun rekonsiliasi fiskal terhadap laporan keuangan komersial tersebut. Oleh karena adanya dasar penyusunan yang berbeda dalam penghitungan laba menurut komersial dengan menurut perpajakan maka menyebabkan perbedaan jumlah antara penghasilan sebelum pajak (laba akuntansi) dengan penghasilan kena pajak (laba fiskal) atau yang dapat disebut dengan book tax differences.

Book tax difference ini menyebabkan perbedaan permanen dan perbedaan temporer. Perbedaan temporer antara laba akuntansi dan pajak dapat mempengaruhi pertumbuhan laba karena komponen book tax differences berupa perbedaan temporer yang tercermin dalam pajak tangguhan dapat digunakan untuk mendeteksi manajemen laba yang dilakukan oleh perusahaan (Phillip et al., 2003). Menurut Zain (2007:232) penyebab perbedaan temporer 
dikarenakan perbedaan metode penyusutan dan amortisasi, penilaian persediaan, dan penghapusan piutang tak tertagih antara laba akuntansi dan pajak. Perbedaan temporer ini menjadikan suatu fenomena bagi manajer untuk memanfaatkan perbedaan ini yang bertujuan untuk menghindari penurunan dan kerugian laba atau dengan kata lain mencegah agar pertumbuhan laba tidak menurun.

Perbedaan temporer ini juga dapat bermanfaat memberikan informasi dalam mengevaluasi kinerja suatu perusahaan yang tercermin dalam pertumbuhan laba. Dalam rangka mengevaluasi kinerja perusahaan yang tercermin dalam pertumbuhan laba, juga diperlukan informasi terkait segmen. Salah satu informasi pada segmen perusahaan yang menjadi perhatian utama para pengguna laporan keuangan adalah informasi pertumbuhan laba. Faktanya menurut telaah literatur yang dilakukan di Indonesia masih sedikit penelitian yang menjelaskan pentingnya informasi segmen perusahaan, terutama terkait pentingnya informasi variabilitas pertumbuhan laba antar segmen perusahaan. Hal ini dikarenakan pelaporan segmen perusahaan terkait pertumbuhan laba seringkali menjadi suatu fenomena masalah yaitu menjadi suatu hal tersulit ketika mengambil keputusan bagi manajer, jadi apapun keputusan yang diambil disatu sisi ada hal yang diuntungkan tapi disisi lain harus ada yang di korbankan, disatu sisi apakah manajer akan menyembunyikan informasi segmen perusahaan atau lebih memilih mengungkapkan informasi asimetri antara manajer dengan stakeholders, sementara di sisi lain pengungkapan ini dapat meningkatkan biaya pernyataan informasi proprietary atau proprietary cost.

Proprietary cost merupakan biaya yang terkait keputusan strategis kompetitor yang menggunakan informasi perusahaan, termasuk informasi privat dalam pengungkapan sukarela. Proprietary cost ini muncul ketika pengungkapan informasi sukarela diutilisasi oleh kompetitor untuk merugikan perusahaan dan pertumbuhan laba perusahaan akan menurun. Pertumbuhan laba perusahaan ini memang diharapkan meningkat oleh investor, sehingga manajer berusaha merencanakan dan memprediksi pertumbuhan laba agar pertumbuhan laba perusahaan meningkat. Dalam merencanakan dan memprediksi pertumbuhan laba di masa mendatang 
E ISSN : 2302 - 1810

DOI : doi.org/1021009/wahana-akuntansi/12.1.05

diperlukan analisis keuangan yang dapat mempengaruhi pertumbuhan laba, salah satunya yaitu dengan menganalisis likuiditas perusahaan. Likuiditas menunjukkan kemampuan perusahaan dalam memenuhi kewajiban jangka pendeknya.

Fenomena yang sering muncul terkait likuiditas adalah perusahaan yang tidak sanggup membayar seluruh atau sebagian utang yang sudah jatuh tempo saat ditagih. Terkadang juga perusahaan tidak memiliki dana untuk membayar kewajibannya tepat waktu. Hal seperti ini akan berdampak pada penurunan laba sehingga pertumbuhan laba ikut menurun. Berdasarkan uraian latar belakang di atas maka peneliti tertarik untuk meneliti dengan judul "Pengaruh Perbedaan Temporer Antara Laba Akuntansi dan Pajak, Proprietary Cost, dan Likuiditas Terhadap Pertumbuhan Laba".

\section{KAJIAN TEORITIK}

\section{Deskripsi Konseptual}

\section{Pertumbuhan Laba}

Pertumbuhan laba merupakan persentase kenaikan laba yang diperoleh perusahaan. Laba akan meningkat atau menurun tiap tahunnya. Peningkatan atau penurunan inilah yang disebut pertumbuhan laba. Pertumbuhan laba merupakan perubahan laba yang dihasilkan oleh perusahaan dari periode ke periode. Pertumbuhan laba ini dapat dijadikan dasar oleh para stakeholder untuk pengambilan keputusan (Fitri, 2014). Menurut Lestari (2011) pertumbuhan laba dihitung dengan cara mengurangkan laba periode sekarang dengan laba periode sebelumnya kemudian dibagi dengan laba pada periode sebelumnya.

\section{Perbedaan temporer antara laba akuntansi dan pajak}

Adanya dasar penyusunan yang berbeda dalam penghitungan laba menurut komersial dengan menurut perpajakan maka menyebabkan perbedaan jumlah antara penghasilan laba sebelum pajak dengan penghasilan kena pajak yang dapat disebut dengan book tax differences (Saputro,2011). Penyebab perbedaan laporan keuangan komersial dan laporan keuangan fiskal adalah karena terdapat perbedaan prinsip akuntansi, perbedaan metode dan prosedur akuntansi, perbedaan 
E ISSN : $2302-1810$

DOI : doi.org/1021009/wahana-akuntansi/12.1.05

pengakuan penghasilan dan biaya, serta perbedaan penghasilan dan biaya (Resmi, 2011:370). Perbedaan penghasilan dan biaya/pengeluaran menurut akuntansi dan menurut fiskal dapat dikelompokkan menjadi perbedaan tetap atau permanen (permanent difference) dan perbedaan temporer atau waktu (timing difference).

Perbedaan permanen terjadi karena transaksi-transaksi pendapatan dan biaya diakui menurut akuntansi komersial dan tidak diakui menurut fiskal. Perbedaan tetap mengakibatkan laba (rugi) bersih menurut akuntansi berbeda (secara tetap) dengan penghasilan (laba) kena pajak menurut fiskal. Sedangkan perbedaan temporer terjadi karena perbedaan waktu pengakuan pendapatan dan biaya dalam menghitung laba. Perbedaan temporer mengakibatkan suatu biaya atau penghasilan telah diakui menurut akuntansi komersial dan belum diakui menurut fiskal, atau sebaliknya. Contoh dari perbedaan temporer yaitu pengakuan biaya piutang tak tertagih, penyusutan, amortisasi, dan lain-lain (Resmi, 2011:373). Perbedaan temporer diukur dengan beban pajak tangguhan dibagi tarif pajak yang berlaku dikali dengan satu dikurang tarif pajak yang berlaku dibagi dengan rata-rata aktiva (Jackson, 2011). Namun menurut Lestari (2011) perbedaan temporer diperoleh dari jumlah perbedaan temporer yang terdapat pada catatan atas laporan keuangan (CALK) dibagi dengan total aset.

\section{Proprietary cost}

Luo et al. (2006) dalam Bestari dan Siregar (2012) menjelaskan bahwa proprietary cost terjadi ketika informasi privat perusahaan yang disampaikan secara sukarela diutilisasi oleh kompetitor untuk mengurangi atau merugikan pendapatan yang diperoleh oleh perusahaan. Biaya yang terkait keputusan strategis kompetitor yang menggunakan informasi perusahaan, termasuk informasi privat dalam 
E ISSN : 2302 - 1810

DOI : doi.org/1021009/wahana-akuntansi/12.1.05

pengungkapan sukarela inilah yang disebut

proprietary cost. Bestari dan Siregar (2012)

yang mengukur proprietary cost dengan

dua proksi yaitu abnormal profitability dan

Indeks Herfindahl yang mengukur

konsentrasi intensitas persaingan. Indeks

Herfindahl diukur dengan cara kuadrat

nilai penjualan perusahaan dibagi dengan

kuadrat jumlah seluruh penjualan

perusahaan di industri yang dijadikan

sampel pada tahun yang sama. Abnormal

profitability diperoleh dengan

menghitung rata-rata return on asset tiga

tahun terakhir dikuragi rata-rata return on

asset tertimbang industri pada periode yang

sama. Rata-rata tertimbang return on asset

yang dihitung dari rata-rata return on

asset tahunan perusahaan setara dengan

laba sebelum pos luar biasa dibagi dengan

total aset pada akhir tahun.

\section{Likuiditas}

Likuiditas adalah kemampuan aktiva

untuk diubah ke dalam bentuk tunai tanpa adanya konsesi harga yang signifikan

(Horne dan Wachowicz, 2005:206). Rasio

likuiditas adalah rasio yang menunjukkan hubungan antara kas dan aset lancar perusahaan lainnya dengan kewajiban lancarnya (Brigham dan Houston, 2010:134). Rasio likuiditas dapat diukur menggunakan:

Current Ratio (CR), rasio ini dihitung dengan membagi aset lancar dengan kewajiban lancar.

(1) Quick Ratio $(\mathrm{QR})$, rasio ini dihitung dengan mengurangi persediaan dengan aset lancar, kemudian membagi sisanya dengan kewajiban lancar.

\section{Kerangka Teoritik}

Perbedaan temporer antara laba akuntansi dan pajak dapat mempengaruhi pertumbuhan laba karena komponen book tax differences berupa perbedaan temporer

Jurnal Ilmiah Wahana Akuntansi

Volume 12 No.01, Tahun 2017 
E ISSN : 2302 - 1810

DOI : doi.org/1021009/wahana-akuntansi/12.1.05

yang tercermin dalam pajak tangguhan dapat digunakan untuk mendeteksi manajemen laba yang dilakukan oleh perusahaan (Phillip et al., 2003). Perbedaan temporer ini menjadikan suatu fenomena bagi manajer untuk melakukan praktik manajemen laba yang bertujuan untuk menghindari penurunan dan kerugian laba atau dengan kata lain mencegah agar pertumbuhan laba tidak menurun. Manajer juga memanfaatkan perbedaan temporer ini seperti metode penilaian persediaan dan penyusutan untuk menghindari penurunan pertumbuhan laba. Dalam rangka mengevaluasi kinerja perusahaan yang tercermin dalam pertumbuhan laba, juga diperlukan informasi terkait segmen. Salah satu informasi pada segmen perusahaan yang menjadi perhatian utama para pengguna laporan keuangan adalah informasi pertumbuhan laba. Hal ini dikarenakan pelaporan segmen perusahaan terkait pertumbuhan laba seringkali menjadi suatu fenomena masalah yaitu menjadi suatu keputusan yang sulit diambil oleh manajer, apakah manajer akan menyembunyikan informasi segmen perusahaan atau lebih memilih mengungkapkan informasi asimetri antara manajer dengan stakeholders, sementara di sisi lain pengungkapan ini dapat meningkatkan biaya pernyataan informasi proprietary atau proprietary cost. Proprietary cost merupakan biaya yang terkait keputusan strategis kompetitor yang menggunakan informasi perusahaan, termasuk informasi privat dalam pengungkapan sukarela. Proprietary cost ini muncul ketika pengungkapan informasi sukarela diutilisasi oleh kompetitor untuk merugikan perusahaan yang dapat mengurangi pertumbuhan laba. Sementara pertumbuhan laba suatu perusahaan akan diharapkan meningkat oleh investor dan oleh karena itu manajer berusaha merencanakan dan memprediksi 
E ISSN : 2302 - 1810

DOI : doi.org/1021009/wahana-akuntansi/12.1.05

pertumbuhan laba agar pertumbuhan laba perusahaan meningkat. Dalam merencanakan dan juga memprediksi pertumbuhan laba di masa yang akan mendatang diperlukan analisis keuangan yang dapat mempengaruhi pertumbuhan laba yaitu dengan menganalisis likuiditas. Likuiditas didefinisikan sebagai rasio yang dapat mengukur likuiditas jangka pendek perusahaan dengan melihat aktiva lancar terhadap hutang lancar yang merupakan kewajiban perusahaan. Semakin besar aktiva lancar, semakin besar pula tingkat likuiditas perusahaan. Namun, likuiditas yang sangat tinggi ini menyebabkan banyak dana yang tidak efektif sehingga akan mengurangi kemampuan perusahaan dalam memperoleh labaatau mengurangi tingkat profitabilitas suatu perusahaan. Likuiditas yang meningkat ini merupakan biaya dari kemampuan memperoleh laba yang menurun sehingga pertumbuhan laba ikut menurun. Berikut adalah kerangka pemikiran atas permasalahan penelitian yang telah dirumuskan sebelumnya.

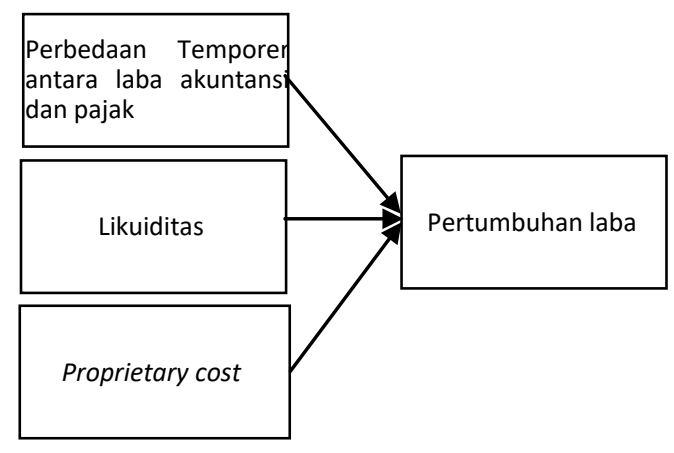

\section{Gambar: Kerangka Berpikir}

Sumber : Data Diolah Oleh Penulis (2014)

Berdasarkan kerangka pemikiran dan asumsi di atas, maka dibuat hipotesis sebagai berikut :

$\mathrm{H}_{1}$ : Perbedaan temporer antara laba akuntansi dan pajak berpengaruh terhadap pertumbuhan laba.

$\mathrm{H}_{2}$ : Proprietary Cost berpengaruh terhadap

Jurnal Ilmiah Wahana Akuntansi

Volume 12 No.01, Tahun 2017 
E ISSN : 2302 - 1810

DOI : doi.org/1021009/wahana-akuntansi/12.1.05

pertumbuhan laba

$\mathrm{H}_{3}$ : Likuiditas berpengaruh terhadap pertumbuhan laba.

\section{OBJEK DAN METODOLOGI PENELITIAN Tujuan Penelitian}

Tujuan penelitian ini ialah untuk :

1. Mengetahui pengaruh perbedaan temporer antara laba akuntansi dan pajak terhadap pertumbuhan laba.

2. Mengetahui pengaruh proprietary cost terhadap pertumbuhan laba.

3. Mengetahui pengaruh likuiditas terhadap pertumbuhan laba.

\section{Objek dan Ruang Lingkup Penelitian}

Objek dalam penelitian " Pengaruh Perbedaan Temporer Antara Laba Akuntansi dan Pajak, Proprietary Cost, dan Likuiditas Terhadap Pertumbuhan Laba" adalah laporan keuangan perusahaan manufaktur yang terdaftar di Busa Efek Indonesia (BEI) periode 2011-2012. Peneliti membatasi ruang lingkup penelitian ini pada pengaruh perbedaan temporer antara laba akuntansi dan pajak, proprietary cost, dan likuiditas terhadap pertumbuhan laba.

\section{Metode Penelitian}

Penelitian ini menggunakan metode deskriptif kuantitatif. Metode deskriptif kuantitatif menggunakan cara-cara tertentu dalam mengumpulkan, mengolah, dan menganalisis data dengan teknik statistik, mengambil kesimpulan secara generalisasi untuk membuktikan adanya pengaruh perbedaan temporer antara laba akuntansi dan pajak, proprietary cost, dan likuiditas terhadap pertumbuhan laba pada perusahaan manufaktur yang terdaftar di BEI periode tahun 2011-2012. Jenis dan Sumber Data Penelitian ini menggunakan data sekunder yaitu berupa laporan keuangan tahunan perusahaan manufaktur yang sudah diaudit yang terdaftar di BEI dengan akhir tahun pembukuan pada tanggal 31 Desember 20112012. Sumber data laporan keuangan perusahaan yang telah diaudit tahun 20112012 dapat diperoleh dari Bursa Efek Indonesia atau Indonesia Stock Exchange (IDX). Populasi dalam penelitian ini adalah perusahaan manufaktur yang terdaftar di BEI dan mempublikasikan laporan keuangan auditan per 31 Desember secara konsisten dan lengkap dari tahun 2011-2012. Metode pemilihan sampel penelitian menggunakan purposive sampling.

\section{Operasionalisasi Variabel Penelitian}

1) Pertumbuhan Laba

Pertumbuhan laba merupakan perubahan

Jurnal Ilmiah Wahana Akuntansi

Volume 12 No.01, Tahun 2017 
E ISSN : 2302 - 1810

DOI : doi.org/1021009/wahana-akuntansi/12.1.05

kenaikan laba yang diperoleh atau dihasilkan perusahaan dari tahun ke tahun (Fitri,2014). Pengukuran variabel menggunakan Net Income (NI) yang membagi laba perusahaan pada periode sekarang dikurang laba perusahaan pada tahun sebelumnya dibagi dengan laba perusahaan pada tahun sebelumnya..

2) Perbedaan temporer antara laba akuntansi dan pajak

Perbedaan temporer atau sementara merupakan perbedaan yang terjadi karena waktu pengakuan pendapatan dan biaya dalam menghitung laba (Resmi, 2011:373). Pengukuran variabel dengan membagi jumlah perbedaan temporer yang terdapat pada catatan atas laporan keuangan dibagi dengan total aset.

\section{3) Proprietary Cost Proprietary cost} merupakan biaya yang terjadi ketika informasi privat perusahaan yang disampaikan secara sukarela diutilisasi oleh kompetitor untuk mengurangi atau merugikan pendapatan yang diperoleh oleh perusahaan (Bestari dan Siregar,2012). Pengukuran variabel menggunakan Indeks Herfindahl dengan membagi kuadrat nilai penjualan suatu perusahaan dengan kuadrat jumlah seluruh penjualan perusahaan di industri yang dijadikan sampel pada tahun yang sama.

4) Likuiditas

Likuiditas merupakan kemampuan aktiva untuk diubah ke dalam bentuk tunai tanpa adanya konsesi harga yang signifikan (Horne dan Wachowicz, 2005:206). Pengukuran variabel menggunakan current ratio yang membagi aktiva lancar dengan hutang lancar.

\section{Teknik Analisis Data}

Dalam penelitian ini, teknik analisis yang digunakan adalah analisis berganda. Analisis

berganda ini dilakukan dengan terlebih dahulu melakukan pengujian statistik deskriptif. Statistik deskriptif yaitu memberikan gambaran suatu data dimana data ini dilihat dari nilai rata-rata (mean), standar deviasi varian, maksimum, dan minimun (Ghozali,2011:19). Selain itu juga dilakukan uji asumsi klasik yang meliputi diantaranya uji normalitas, multikolinearitas, autokorelasi, dan heteroskedastisitas.

\section{PEMBAHASAN}

Dari hasil analisa dengan menggunakan analisis regresi linier berganda dan pengujian hipotesis dapat dijelaskan faktorfaktor yang mempengaruhi pertumbuhan laba. Sebelum dilakukan analisis, terlebih

Jurnal Ilmiah Wahana Akuntansi

Volume 12 No.01, Tahun 2017 
E ISSN : 2302 - 1810

DOI : doi.org/1021009/wahana-akuntansi/12.1.05

dahulu dilakukan pengujian asumsi klasik. Hasil dari pengujian asumsi klasik menunjukkan bahwa variabel perbedaan temporer antara laba akuntansi dan pajak, proprietary cost dan likuiditas setelah di log natural menunjukkan memenuhi asumsi klasik dan berdistribusi normal.

\section{Pengaruh Perbedaan Temporer} Antara Laba Akuntansi dan Pajak

\section{Terhadap Pertumbuhan laba}

Berdasarkan hasil uji parsial (uji t) maka diperoleh hasil bahwa nilai koefisien sebesar - 0.201 dan nilai thitung -1.711 memiliki nilai negatif yang artinya memiliki arah negatif dan nilai tabel > thitung $(2.032>$ 1.711) dengan tingkat signifikansi sebesar 0.096 lebih besar dari taraf signifikansi sebesar 0.05. Dengan demikian maka H1 ditolak.

Artinya perbedaan temporer antara laba akuntansi dan pajak tidak mempengaruhi pertumbuhan laba. Hasil penelitian ini didukung dengan teori dari Lestari (2011) yang menyatakan bahwa perbedaan temporer berpengaruh terhadap beban pajak perusahaan melalui aset pajak tangguhan dan kewajiban pajak tangguhan. Kenaikan neto aset pajak tangguhan menyebabkan pengurangan beban pajak perusahaan, sebaliknya kenaikan neto kewajiban pajak tangguhan menyebabkan kenaikan beban pajak perusahaan. Jumlah kenaikan neto aset pajak tangguhan ataupun kewajiban pajak tangguhan tidak terlalu signifikan besarnya terhadap beban pajak penghasilan atau beban pajak perusahaan sehingga tidak akan mempengaruhi pertumbuhan laba. Hasil ini sejalan dengan penelitian yang telah dilakukan oleh Lestari (2011) dan Fitri (2014) yang juga mendapatkan hasil perbedaan temporer tidak berpengaruh dan tidak signifikan terhadap pertumbuhan laba.

\section{Pengaruh Proprietary Cost Terhadap Pertumbuhan Laba}

Berdasarkan hasil uji parsial (uji t) maka diperoleh hasil bahwa nilai koefisien proprietary costsebesar -0.034 dan nilai thitung -0.821 memiliki nilai negative yang artinya memiliki arah negatif dan nilai tabel $>$ thitung $(2.032>0.821)$ dengan tingkat signifikansi sebesar 0.417 lebih besar dari taraf signifikansi sebesar 0.05. Maka proprietary cost tidak berpengaruh dan tidak signifikan terhadap pertumbuhan laba. Dengan demikian maka $\mathrm{H} 2$ ditolak.

Menurut Bestari dan Siregar (2012) 
E ISSN : 2302 - 1810

DOI : doi.org/1021009/wahana-akuntansi/12.1.05

proprietary cost yang diukur dengan Indeks Herfindahl menunjukkan suatu konsentrasi intensitas persaingan antar perusahaan. Jadi Indeks Herfindahl lebih memfokuskan kepada suatu intensitas persaingan perusahaan daripada pertumbuhan laba perusahaan itu sendiri. Hal itulah yang menyebabkan proprietary cost tidak berpengaruh terhadap pertumbuhan laba. Nilai proprietary cost yang dihitung menggunakan Index Herfindahl menghasilkan angka yang rendah yang menunjukkan konsentrasi kekuatan persaingan pasar perusahaan cukup rendah. Hal ini dibuktikan dengan nilai mean atau rata-rata proprietary cost perusahaan manufaktur dari tahun 2011 sampai 2012 yang rendah yaitu sebesar 0.00848439 yang menunjukkan rata-rata konsentrasi kekuatan persaingan pasar perusahaan cukup rendah. Nilai proprietary cost yang rendah ini disebabkan penjualan bersih tiap perusahaan tidak sebanding dengan jumlah seluruh penjualan di industry sehingga tidak mempengaruhi pertumbuhan laba. Hasil penelitian ini konsisten atau sejalan dengan hasil penelitian dari Bestari dan Siregar (2012) dan Wang et al. (2011).

\section{Pengaruh Likuiditas Terhadap}

Jurnal Ilmiah Wahana Akuntansi

\section{Pertumbuhan Laba}

Berdasarkan hasil uji parsial (uji t) maka diperoleh hasil bahwa nilai koefisien 0.852 dan thitung sebesar -3.395 yang memiliki nilai minus yang artinya memiliki arah negatif dan tabel < thitung $(2.032<3.395)$ dengan tingkat signifikansi sebesar 0.002 lebih kecil dari taraf signifikansi sebesar 0.05. Maka likuiditas berpengaruh negatif dan signifikan terhadap pertumbuhan laba. Dengan demikian maka $\mathrm{H} 3$ diterima.

Hal ini menunjukkan bahwa likuiditas berpengaruh negatif dan signifikan terhadap pertumbuhan laba. Artinya ketika tingkat likuiditas perusahaan meningkat maka pertumbuhan laba perusahaan justru akan menurun. Sebaliknya apabila tingkat likuiditas perusahaan menurun maka pertumbuhan laba perusahaan justru akan meningkat. Jadi, antara likuiditas dan pertumbuhan laba memiliki hubungan yang berbanding terbalik. Hasil penelitian tersebut didukung teori dari Prihartanty (2011) yang mengatakan bahwa ketika tingkat likuiditas perusahaan meningkat maka laba perusahaan akan menurun. Aktiva lancar yang semakin besar akan meningkatkan likuiditas perusahaan. Namun tingkat likuiditas yang semakin besar ini tidak hanya mampu untuk menutupi kewajiban

Volume 12 No.01, Tahun 2017 
E ISSN : $2302-1810$

DOI : doi.org/1021009/wahana-akuntansi/12.1.05

jangka pendeknya tetapi juga dapat mengurangi kemampuan perusahaan dalam memperoleh laba. Hal ini disebabkan oleh banyaknya dana yang tidak efektif sehingga

\section{Pengaruh Perbedaan Temporer Antara}

\section{Laba Akuntansi dan Pajak, Proprietary} Cost, dan Likuiditas Terhadap

\section{Pertumbuhan Laba}

Pengaruh perbedaan temporer antara laba akuntansi dan pajak, proprietary cost, dan likuiditas bersama-sama atau secara simultan memiliki pengaruh positif dan signifikan terhadap pertumbuhan laba. Hal ini dapat dilihat dari nilai signifikansinya pada tabel anova yang menunjukkan nilai signifikan dibawah 5\% atau 0.05 sebesar 0.014 lebih kecil dari 0.05, hal ini juga dapat dilihat dari nilai $F_{\text {tabel }}<$ Fhitung $(2.883<4.059)$. Dengan demikian perbedaan temporer antara laba akuntansi dan pajak, proprietary cost, dan likuiditas bersama-sama atau secara simultan memiliki pengaruh positif dan signifikan terhadap pertumbuhan laba.

Adanya kombinasi perbedaan temporer antara laba akuntansi dan pajak, proprietary cost, dan likuiditas merupakan beberapa faktor yang dapat dijadikan bahan pertimbangan dalam meningkatkan pertumbuhan laba perusahaan. Ketika laba perusahaan akan menurun. Hasil penelitian ini konsisten atau sejalan dengan hasil penelitian dari Prihartanty (2011).

penjualan produk perusahaan meningkat, sebenarnya perusahaan cenderung untuk menyembunyikan informasi segmen untuk memberikan informasi produk penjualan mana yang paling menghasilkan keuntungan besar karena informasi ini dapat diutilisasi oleh perusahaan lain dan menimbulkan proprietary cost yang dapat mengurangi pertumbuhan laba. Apabila penjualan meningkat dan beresiko menimbulkan proprietary cost ini maka laba perusahaan akan meningkat dimana pajak pun akan meningkat. Pajak ini akan mengurangi laba sehingga sebisa mungkin perusahaan mengecilkan pajak menurut standar akuntansi yang berlaku dengan cara memanfaatkan perbedaan temporer antara laba akuntansi dan pajak. Perbedaan temporer ini misalnya perbedaan metode penyusutan dan masa manfaat yang digunakan dalam perhitungan laba akuntansi dengan laba fiskal (pajak). Perbedaan ini dapat dimanfaatkan untuk mengecilkan pajak karena ada metode penyusutan dan perhitungan persediaan yang diakui oleh 
E ISSN : 2302 - 1810

DOI : doi.org/1021009/wahana-akuntansi/12.1.05

akuntansi tapi tidak diakui dalam pajak. Apabila pengurang pajak kecil maka laba perusahaan akan meningkat dan apabila laba perusahaan meningkat tiap periodenya maka pertumbuhan laba perusahaan pun akan meningkat. Pertumbuhan laba yang meningkat ini menunjukkan tingkat likuiditas yang menurun.

\section{KESIMPULAN DAN SARAN}

\section{Kesimpulan}

Berdasarkan hasil analisis dan pembahasan, maka kesimpulan yang bisa diperoleh adalah:

1. Pengaruh Perbedaan temporer antara laba akuntansi dan pajak terhadap Pertumbuhan Laba. Perbedaan temporer antara laba akuntansi dan pajak tidak berpengaruh terhadap pertumbuhan

laba. Perbedaan temporer antara laba akuntansi dan pajak tidak berpengaruh terhadap pertumbuhan laba karena perbedaan temporer antara laba akuntansi dan pajak berpengaruh terhadap beban pajak perusahaan melalui aset pajak tangguhan dan kewajiban pajak tangguhan. Jumlah kenaikan neto aset pajak tangguhan ataupun kewajiban pajak tangguhan tidak terlalu signifikan besarnya terhadap beban pajak penghasilan atau beban pajak perusahaan sehingga tidak akan mempengaruhi pertumbuhan laba.

2. Pengaruh Proprietary cost terhadap pertumbuhan laba. Proprietary cost tidak berpengaruh terhadap pertumbuhan laba. Hal ini dikarenakan

proprietary cost yang diukur menggunakan Index Herfindahl lebih memfokuskan kepada suatu konsentrasi intensitas persaingan antar perusahaan. Nilai proprietary cost yang rendah ini disebabkan penjualan bersih tiap perusahaan tidak sebanding atau lebih kecil dengan jumlah seluruh penjualan di industri yang dijadikan sampel yang jauh lebih besar sehingga nilai proprietary costyang rendah ini tidak akan mempengaruhi pertumbuhan laba.

3. Pengaruh likuiditas terhadap pertumbuhan laba. Likuiditas berpengaruh negatif terhadap pertumbuhan laba. Artinya ketika tingkat likuiditas

perusahaan meningkat maka pertumbuhan laba perusahaan justru akan menurun. Sebaliknya apabila tingkat likuiditas perusahaan menurun maka pertumbuhan laba perusahaan justru akan meningkat.

4. Pengaruh Perbedaan temporer antara laba akuntansi dan pajak, proprietary cost, dan likuiditas terhadap pertumbuhan laba Perbedaan temporer antara laba akuntansi dan 
E ISSN : $2302-1810$

DOI : doi.org/1021009/wahana-akuntansi/12.1.05

pajak, proprietary cost, dan likuiditas bersamasama atau secara simultan memiliki pengaruh positif dan signifikan terhadap pertumbuhan laba. Apabila penjualan meningkat akan beresiko menimbulkan proprietary cost dan laba perusahaan akan meningkat dalam hal ini pajak pun akan meningkat. Pajak ini akan mengurangi laba sehingga sebisa mungkin perusahaan mengecilkan pajak menurut standar akuntansi yang berlaku dengan cara memanfaatkan perbedaan temporer antara laba akuntansi dan pajak untuk mengecilkan pajak perusahaan. Apabila pengurang laba yaitu pajak perusahaan kecil maka pertumbuhan laba perusahaan akan meningkat. Pertumbuhan laba yang meningkat menunjukkan tingkat likuiditas yang menurun.

\section{Implikasi}

1. Perbedaan temporer antara laba akuntansi dan pajak memiliki efek bagi manajer perusahaan dalam menentukan beban pajak perusahaan melalui aset pajak tangguhan dan kewajiban pajak tangguhan. Beban pajak tangguhan perusahaan ini akan berdampak pada perusahaan sebagai pengurang laba sehingga perbedaan temporer antara laba akuntansi dan pajak berpusat pada laba perusahaan seperti pada teori entitas yang berpusat pada laba dan konsekuensinya berorientasi pada laporan laba rugi. Perbedaan temporer antara laba akuntansi dan pajak juga memiliki efek bagi investor untuk menentukan investasinya dan berguna untuk mengevaluasi kinerja perusahaan.

2. Proprietary cost yang diukur menggunakan Index Herfindahl berdampak bagi perusahaaan dalam mengukur konsentrasi intensitas persaingan antar perusahaan dan konsekuensinya berorientasi pada penjualan perusahaan. Penjualan perusahaan ini juga terkait pengungkapan informasi segmen yang memuat keuntungan dari setiap penjualan. Hal ini berhubungan dengan cara-cara penyusunan laporan keuangan yang mempertimbangkan keputusan perusahaan untuk mengungkapkan atau tidak mengungkapkan informasi segmen seperti pada proprietary theory yang menyatakan sudut pandang dari kelompok pemilik sebagai pusat kepentingan dicerminkan dalam cara-cara dimana catatan akuntansi disimpan dan laporan keuangan disusun. Proprietary cost berguna bagi para investor dan kompetitor untuk menilai penjualan perusahaan yang paling menguntungkan sehingga bagi investor memiliki efek dalam penentuan investasinya. 
E ISSN : $2302-1810$

DOI : doi.org/1021009/wahana-akuntansi/12.1.05

3. Likuiditas berpengaruh negatif terhadap pertumbuhan laba berdampak pada perusahaan terhadap penggunaan dana dalam membiayai hutang perusahaan. Seperti pada teori dana memandang unit bisnis sebagai unit yang terdiri dana ekonomi dan kewajiban serta pembatasan yang terkait penggunaan dari dana itu sendiri. Likuiditas juga memiliki efek bagi manajer perusahaan dalam menentukan pertumbuhan laba perusahaan dan juga berguna bagi para manajer dan investor dalam mengevaluasi kinerja suatu perusahaan dan meramalkan kemampuan perusahaan dalam membiayai hutangnya.

4. Perbedaan temporer antara laba akuntansi dan pajak, proprietary cost, dan likuiditas secara bersama-sama dapat memiliki efek dalam menaikan pertumbuhan laba dan berdampak bagi manajer memanfaatkan perbedaan temporer antara laba akuntansi dan pajak, proprietary cost, dan likuiditas untuk mencegah agar pertumbuhan laba tidak menurun karena manajer memiliki informasi yang lebih banyak daripada investor atau pemilik. Seperti pada teori informasi asimetrik menyebutkan antara manajer dan pemilik mempunyai informasi yang berbeda tentang perusahaan sehingga dampaknya manajer memiliki informasi yang lebih banyak dari pemilik. Informasi perbedaan temporer antara laba akuntansi dan pajak, proprietary cost, dan likuiditas berguna bagi manajer untuk menaikan pertumbuhan laba sehingga investor tertarik untuk berinvestasi.

\section{Saran}

Saran yang dapat diberikan berdasarkan simpulan yang telah disampaikan sebagai berikut :

Bagi Peneliti :

1. Penelitian selanjutnya sebaiknya menambah jangka waktu penelitian menjadi tiga sampai lima tahun agar dapat diperoleh sampel yang lebih banyak sehingga dapat lebih menggambarkan kondisi perusahaan manufaktur yang terdaftar di BEI.

2. Penelitian selanjutnya sebaiknya menambahkan faktor lain sebagai variabel independen yang dapat mempengaruhi pertumbuhan laba. Faktor lain yang dapat dimasukkan dalam penelitian selanjutnya adalah seperti ukuran perusahaan, agency cost, financial incentive dan lain sebagainya agar lebih mampu menjelaskan variabel pertumbuhan laba.

3. Penelitian selanjutnya dapat mencari proksi lain untuk menghitung variabel- 
E ISSN : 2302 - 1810

DOI : doi.org/1021009/wahana-akuntansi/12.1.05

variabel dalam penelitian ini seperti pada variabel independen likuiditas dapat digunakan proksi lain seperti quick ratio agar hasil yang diperoleh maksimal.

Bagi Perusahaan :

1. Perusahaan sebaiknya memperhatikan tingkat likuiditas perusahaan sebab likuiditas berpengaruh negatif terhadap pertumbuhan laba dan likuiditas menunjukan besarnya pertumbuhan laba.

2. Perusahaan sebaiknya memanfaatkan ketiga variabel independen secara bersamasama dalam mengatur pertumbuhan laba perusahaan sebab berdasarkan uji simultan variabel independen perbedaan temporer antara laba akuntansi dan pajak, proprietary cost, dan likuiditas berpengaruh terhadap pertumbuhan laba sehingga manajer dapat memanfaatkan ketiga variabel independen ini untuk menaikan pertumbuhan laba.

Bagi Investor :

1. Dalam menentukan investasinya, sebaiknya investor memperhatikan tingkat likuiditas perusahaan dengan baik karena tingkat likuiditas berpengaruh terhadap pertumbuhan laba perusahaan dan tingkat likuiditas dapat menentukan tingkat dividen yang akan diterima investor. Apabila tingkat likuiditas rendah maka pertumbuhan laba perusahaan meningkat dan tingkat dividen yang akan diterima investor juga besar.

\section{DAFTAR PUSTAKA}

Adi, Base. Metode Kuantitatif. 2010. http://baseadi.blogspot.com/2010/06/metode -kuantitatif.html (Diakses tanggal 23 Maret 2014).

Adisetiawan, R. "Analisis Pengaruh Kinerja Keuangan Dalam Memprediksi Pertumbuhan Laba". Universitas Batanghari. 2013, hal. 1-12.

Agoes, Sukrisno., dan Trisnawati, Estralita. “Akuntansi Perpajakan" Edisi 2. Jakarta: Salemba Empat. 2009.

Bakrie Global. Pertumbuhan Bakrie Tertinggi. http://www.bakrieglobal.com/news /read/642/Pertumbuhan-Bakrie-tertinggi

(Diakses tanggal 13 April 2014).

Berger, Philip G., dan Hann, Rebecca N. "Segment Profitability and the Propietary and Agency Costs of Disclosure”. University of Southern California. 2007, hal. 1-37.

Bestari, Megalia., dan Siregar, Sylvia Veronica. "Determinan Motif Pengungkapan Variasi Pertumbuhan Laba Antar Segmen Perusahaan Manufaktur yang Terdaftar di Indonesia”. Universitas 
E ISSN : 2302 - 1810

DOI : doi.org/1021009/wahana-akuntansi/12.1.05

Indonesia. 2012, hal. 1-25.

Bhat, vasantahakumar N. "Productivity Strategies In The Retail Industry”. Pace University, New York. 2008, hal 1-15.

Bisnis Indonesia.Merck mark-up pendapatan, bursa dunia anjlok. 2002. http://cybertainment.cbn.net.id/cbprtl/cybernew s/detail.aspx $? \mathrm{x}=$ Economy $\& y=$ cybernews $|0| 0 \mid$ 3|3875 (Diakses tanggal 24 Maret 2014).

Brigham, Eugene F., dan Houston, Joel F. "Dasar-dasar Manajemen Keuangan. Edisi 11. Jakarta: Salemba Empat. 2010.

Burhanuddin, Muhammad. Koefisien Korelasi, Signifikansi, \& Determinasi. 2012. http://alvinburhani.wordpress.com/2012/06/28/ koefisien-korelasi-signifikansi-determinasi/

(Diakses tanggal 23 Maret 2014).

Cohen, Daniel A. "Financial Reporting Quality and Propietary Cost”. Northwestern University 2001 Sheridan Road, Evanston IL. Juni 2002, hal. 1-38.

Fadlilah, Anik. "Determinan dan Modernisasi Book Tax Differences Terhadap Pertumbuhan Laba Perbankan. Universitas Negeri Semarang. November 2013, hal. 1-7.

Fitri, Dinel. "Pengaruh Book-Tax Terhadap Pertumbuhan Laba". Universitas Negeri Padang. 2014, hal. 1-22.

Garrison, noreen dan Brewer. "Akuntansi Manajerial”. Edisi 11. Jakarta: Salemba
Empat. 2007.

Ghozali, Imam. Analisis Multi Variate Dengan Program IBM SPSS 19. Edisi 5. Semarang : Badan Penerbit Universitas Diponegoro. 2011.

Ginting, Litna. Uji Asumsi Klasik. 2014. http://litnastory.blogspot.com/2014/02/ ujjiasumsi-klasik.html (Diakses tanggal 23 Maret 2014).

Habsari, Hanifah Putri. Tugas Ebis dan

Profesi. 2010. http://hiraspasaribu. blogspot.com/2010/05/tugas-ebis-dan-

profesihanifah-phnim.html(Diakses tanggal 13 April 2014).

Harjito, Agus D. "Dasar-dasar Teori Keuangan”. Edisi 1. Jakarta EKONISIA. 2012.

Hartini, Windi. "Pengaruh Financial Ratio terhadap Pertumbuhan Laba Dengan Pengungkapan Corporate Social Responsibility Sebagai Variabel Pemoderasi”. Universitas Negeri Semarang. Agustus 2012, hal. 1-7.

Hidayat, Anwar. Uji Statistik. 2013. http://statistikian.blogspot.com/2013/01/uji-fdan-uji-t.html. (Diakses tanggal 23 Maret 2014).

Horne, James C. Van dan Wachowicz, John M. "Prinsip-prinsip Manajemen Keuangan". Edisi 12. Jakarta: Salemba 
E ISSN : $2302-1810$

DOI : doi.org/1021009/wahana-akuntansi/12.1.05

Empat. 2005.

http://www.idx.co.id/ (Diakses 12 April 2014).

Hutabarat, Loesiana Maulina. "Pengaruh BookTax Differences Terhadap Pertumbuhan Laba”. Universitas Negeri Gorontalo. Hal. 116.

Jackson, Mark. "Book-Tax Differences and Earnings Growth”. University of Nevada.

Desember 2011, hal. 1-44.

Joniansyah. Terlilit Utang, Dua Perusahaan di

Tangerang Dinyatakan Pailit. 2011. http://www.tempo.co/read/news/2011/06/16/09 $\underline{\text { 0341109/Terlilit-Utangi-Dua-Perusahaan-di- }}$

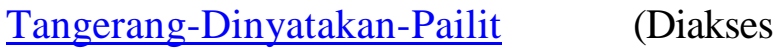
tanggal 24 Maret 2014).

$\mathrm{Kab}$ ar Bis nis. Gagal merger dengan Pan as on ic Pio n eer akh ir i p ro du ks i TV

plasma.2009.http://www.kabarbisnis.com/ane ka-bisnis/284740
Nugroho, $\mathrm{Mu}$ khammad Luth $\mathrm{f}$ i. Permas a lah an Terjad i Di PT. Bum i Resources .

2014.http://mukhammadluthfinugroho.word press.com/2014/01/20/permasalahan-yangterjadi-di-pt-bumi-resorces-bumi-_tugas$\underline{\text { kelompok-softskill/(Diakses }}$ tanggal 13 April 2014).

Pedoman Penulisan Skripsi Sarjana Ekonomi. Jakarta, FE UNJ. 2012.

Philip, J., M. Pincus, and S. Rego. 3“"Earnings Management: New Evidence Based On Deferred Tax Expense”.American Accounting Association. 2003, hal. 491-521.

Prihartanty, Rima. "Analisis Pengaruh Rasio Likuiditas, Rasio Leverage, Rasio Aktivitas, dan Rasio Profitabilitas Terhadap Net Income Growth. 2011, hal. 1-15.

Qamariah, Nurul. Bapepam Denda Mantan Direksi Indofarma Rp $500 \quad$ Juta. 2004 hlp//inancedetikcomkead/2004/1108/165712/23807//6bapepam-

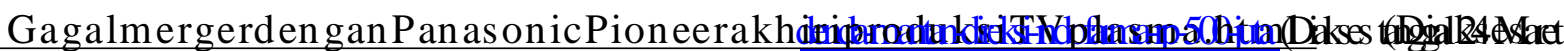
tanggal 13 April 2014). 2014).

Kristanto, $\quad$ Fransiskus $\quad$ Asisi Verry.Qamariał.ji

Nutolkorelasi. Lepasn2y0a13.

Andalan http://asisiverry.blogspot.com/2013/08/ujiautokorelasi.html._(Diakses tanggal 23 Maret 2014).

Lestari, Budi. "Analisis Pengaruh Book-Tax Differences Terhadap Pertumbuhan Laba”. 2011, hal. 1-31. 7/1029585/6/2/lepasnya-andalan-grup-

bakrie(Diakses tanggal 24 Maret 2014).

Rahman, Jaka. Pengaturan Standar Akuntansi.

2012. http://www.yakasan.net/2012

/12/pengaturan-standar-1.html

(Diakses

Jurnal Ilmiah Wahana Akuntansi

Volume 12 No.01, Tahun 2017 
E ISSN : 2302 - 1810

DOI : doi.org/1021009/wahana-akuntansi/12.1.05

tanggal 23 Maret 2014).

Resmi, Siti. "Perpajakan Teori dan Kasus".

Edisi 5. Jakarta: Salemba Empat. 2009.

Resmi, Siti. "Perpajakan Teori dan Kasus".

Edisi 6. Jakarta: Salemba Empat. 2011.

Riahi, Ahmed., dan Belkaoui. "Teori

Akuntansi”. Edisi 5. Jakarta: Salemba Empat.

2006.

Saputro, Nugroho Adi. "Pengaruh Book-Tax

Differences Terhadap Pertumbuhan Laba".

2011, hal. 1-24.

Solihin, Asep. Metode Penelitian. 2012.

http://asep-

solihin.blogspot.com/2012/11/metode-

penelitian2.html._(Diakses tanggal 23 Maret

2014).

Taruh, Victorson. “Analisis Rasio Keuangan

Dalam Memprediksi Pertumbuhan Laba

Pada Perusahaan Manufaktur di BEI’. Hal. 1-

10.

Wang et al. "Strategic Revelation of

Differences in Segment Earning Growth".

1300 Sunny Ave Lawrence, Kansas. May

2011, hal. 1-21.

Warthy, Shanty. "Kinerja Keuangan

Perusahaan Dalam Memprediksi

Pertumbuhan Laba Pada Perusahaan

Manufaktur Yang Terdaftar di Bursa Efek

Indonesia Periode Tahun 2005-2010”. STIE

PERBANAS Surabaya. 2012, hal. 1-15.
Wijaya, Adrianto Purnomo. "Analisis Rasio

Keuangan Dalam Merencanakan

Pertumbuhan Laba: Perspektif Teori Signal”.

Hal. 1-8.

www.sahamok.com (Diakses 12 April 2014).

Yulianto, Erwin. Manajemen Laba,

Baik atau Buruk?. 2011.

http://estehmanishangatnggakpakegula.blogspo

t.com/2011/03/manajemen-laba-baik-atau-

buruk-5.html

(Diakses tanggal 24Maret2014).

Zain, Mohammad. "Manajemen Perpajakan".

Edisi 3. Jakarta: Salemba Empat. 2007.

Zanora, Verty. "Pengaruh Likuiditas,

Leverage dan Aktifitas terhadap

Pertumbuhan Laba". Universitas Negeri

Padang. 2003, hal 1-25.

Jurnal Ilmiah Wahana Akuntansi

Volume 12 No.01, Tahun 2017 